\title{
Evaluation of a novel composite inorganic coagulant prepared by red mud for phosphate removal
}

\author{
Ying Zhao ${ }^{\mathrm{a}, \mathrm{b}}$, Lie-yu Zhang ${ }^{\mathrm{a}}$, Fan $\mathrm{Ni}^{\mathrm{b}}{ }^{\mathrm{b}}$, Beidou Xi ${ }^{\mathrm{a}}$, Xunfeng Xia ${ }^{\mathrm{a}}$, Xianjia Peng ${ }^{\mathrm{b}, *}$, Zhaokun Luan ${ }^{\mathrm{b}}$ \\ a Chinese Research Academy of Environmental Sciences, Beijing 100012, PR China \\ ${ }^{\mathrm{b}}$ Research Center for Eco-Environmental Sciences, Chinese Academy of Sciences, Beijing 100085, PR China
}

\section{A R T I C L E I N F O}

Article history:

Received 12 November 2010

Received in revised form 10 January 2011

Accepted 22 January 2011

Available online 23 February 2011

\section{Keywords:}

Phosphate removal

Red mud

Coagulant

Wastewater treatment

\begin{abstract}
A B S T R A C T
Red mud is a waste produced in very large quantities by the aluminum industry. This study relates to a process of transformation of red mud, by treatment in hydrochloric pickle liquor of bauxite, into a novel composite inorganic coagulant that is usable for phosphate removal. The optimum conditions for preparing the composite coagulant with red mud and hydrochloric pickle liquor of bauxite were studied. The effect of various factors such as $\mathrm{pH}$, ionic strength and water temperature on performance of the prepared coagulant was investigated. The coagulation performance of the composite coagulant by treating biologically pretreated municipal sewage and eutrophic water was evaluated. The leaching potential of heavy metals from the coagulant was also investigated. The results showed that the prepared coagulant could reduce the phosphate in values lower than $0.02 \mathrm{mg} / \mathrm{L}$. Compared with commercial polyaluminum chloride coagulant (PACl), it could promote phosphate removal efficiency from $4.9 \%$ to $10.4 \%$. Overall, it is suggested that the composite coagulant is an efficient coagulant and it can be possibly considered as a promising option for tertiary treatment of wastewaters and removing nutrients in eutrophic water, especially for the removal of phosphate. It exhibits better coagulation performance than commercial polyaluminum chloride coagulant.
\end{abstract}

(c) 2011 Elsevier B.V. All rights reserved.

\section{Introduction}

As known, phosphate in wastewaters is regarded as a major nutrient for growth of both vegetable plants and microorganisms. But excess amount of phosphate concentration in the effluent discharge accelerates eutrophication that affects many natural water bodies [14]. Eutrophication of the water bodies is one of the most important environmental problems. Eutrophication can lead to abundant development of aquatic plants, growth of algae and disturb the balance of organisms present in the water [5]. This affects water quality through the depletion of oxygen level because of high biological oxygen demands, and acidification. It in turn can have harmful effects on fish and other aquatic life, microorganism's growth as well as it causes reductions in biodiversity. Consequently, the removal of phosphate in domestic and industrial discharges is absolutely necessary to avoid any kind of problems.

Phosphorus usually occurs in wastewater and surface water in the form of organic phosphates and inorganic phosphates. The

\footnotetext{
* Corresponding author at: State Key Laboratory of Environmental Aquatic Chemistry, Research Center for Eco-Environmental Sciences, Chinese Academy of Sciences 18\# Shuangqing Rd., Haidian District, P.O. Box 2871, Beijing 100085 China. Tel./fax: + 861062849198 .

E-mail addresses: zhao_ying005@yahoo.com.cn (Y. Zhao), xjpeng@rcees.ac.cn (X. Peng).
}

treatment of excessive phosphate can be achieved by several physical, chemical and biological methods [6-10]. Physical methods for water treatment are either too expensive, or not useful with regard to phosphate elimination from water $[11,12]$. The biological method is low cost but the removal efficiency usually does not exceed $30 \%$, which means that remaining phosphate should be removed by other techniques [13]. Chemical removal techniques are widely accepted methods of phosphate removal, especially coagulation process. Coagulation process is highly efficient in removing phosphate. It is regarded as an important option for the tertiary treatment of wastewater, intended for prevention of eutrophication. However, a typical drawback of coagulation process is the high cost associated with the use of metal salts [14]. Therefore, low cost and easily available materials such as fly ash, alum sludge, red mud and other waste materials were used as raw materials for preparation of coagulant to remove phosphate from wastewater [15].

Red mud is a residue of the aluminum industry rejected during the alkaline extraction of alumina from bauxite by the Bayer or sintering process. The quantity of red mud is almost equal to the primary aluminum production: alkaline digestion of $2.5 \mathrm{t}$ of bauxite affords $1 \mathrm{t}$ alumina and about $1.5 \mathrm{t}$ of red mud [16]. Therefore, an average $\mathrm{Al}_{2} \mathrm{O}_{3}$ productivity of $1010^{6} \mathrm{t}_{\text {year }}{ }^{-1}$ involves a mass of by-products of $1510^{6} \mathrm{t}$ year $^{-1}$ discharged as slurry retaining variable water contents in China $[17,18]$. Though being washed and considered as an inert solid waste, red mud remain strongly alkaline and are highly 
corrosive. The high alkaline content of red mud and its enormous quantities caused significant ecological problems and considerable negative environmental effects.

Many efforts are being made globally to find suitable uses for red mud. Some researches focused on the application of red mud in wastewater treatment. Red mud can be used as an adsorbent to remove pollutants and toxic materials from water, such as $\mathrm{Cu}^{2+}$ [19], $\mathrm{Cr}^{3+}$ [20], $\mathrm{C}_{6} \mathrm{H}_{5} \mathrm{OH}$ [21], $\mathrm{Zn}^{2+}$ [22], $\mathrm{F}^{-}$[23], $\mathrm{C}_{16} \mathrm{H}_{18} \mathrm{~N}_{3}$ CISIUPAC [24] and $\mathrm{PO}_{4}^{3-}$ [25].

Red mud is rich in calcium, aluminum, iron and silicon, which are essential raw materials for the production of water and wastewater treatment coagulants. Some team of researchers studied the capacity of untreated red mud to coagulant phosphate [26]. However, the removal efficiency of phosphate obtained during these experiments was limited, only about $20 \%$. These studies thus confirm the need for a novel method to transform red mud into an effective coagulant for phosphate removal.

Hydrochloric pickle liquor of bauxite mainly consists of $\mathrm{AlCl}_{3}$ and $\mathrm{HCl}$. It is usually used as a semi-manufactured material for production of polyaluminum chloride $(\mathrm{PACl})$. In general, some alkalis such as calcium aluminate, caustic soda, lime and aluminum slag react with hydrochloric pickle liquor of bauxite to prepare $\mathrm{PACl}$. If we replace these alkalis with red mud, it may not only reduce the cost for preparing coagulant, but also provide a feasible way to recycle the alkalis in the red mud. Meanwhile, the dissolved metals of red mud in hydrochloric pickle liquor of bauxite could enhance the coagulation efficiency of the coagulant.

The objective of this work was to study the feasibility of a new coagulant prepared by red mud and hydrochloric pickle liquor of bauxite for phosphate removal from wastewater. Firstly, the phosphate removal efficiency of the new coagulant was evaluated to optimize the preparation conditions such as reaction time, reaction temperature and liquid/solid ratio. Secondly, the influence of temperature, $\mathrm{pH}$ and salt concentration on the removal efficiency of phosphate was investigated in order to determine optimal operating conditions. Coagulation experiments were also conducted for the evaluation of the new coagulant capability to treat biologically pre-treated municipal wastewater and eutrophic water, comparing with the coagulation efficiency of conventional coagulant PACl. Finally, the leaching potential of heavy metals from the coagulant was evaluated. The initial results of laboratory scale experiments will be useful for the development of a novel, stabilized and highly effective coagulant.

\section{Materials and methods}

\subsection{Materials}

Red mud used in this study was provided from Shandong Aluminum Corporation, Shandong, China. Before experiments were performed, the red mud was first homogenized and dried. Then the dried red mud samples were crushed in a mortar. The chemical analysis of raw red mud is given in Table 1 [6], where it can be seen

Table 1

Average composition of red mud used (\% by wt.).

\begin{tabular}{lc}
\hline Constituent & $\%(\mathrm{w} / \mathrm{w})$ \\
\hline $\mathrm{SiO}_{2}$ & 18.08 \\
$\mathrm{Fe}_{2} \mathrm{O}_{3}$ & 15.30 \\
$\mathrm{Al}_{2} \mathrm{O}_{3}$ & 8.26 \\
$\mathrm{CaO}$ & 38.02 \\
$\mathrm{MgO}$ & 1.63 \\
$\mathrm{Na} \mathrm{N}_{2} \mathrm{O}$ & 3.55 \\
$\mathrm{~K}_{2} \mathrm{O}$ & 0.36 \\
$\mathrm{TiO}_{2}$ & 4.51 \\
\hline
\end{tabular}

that red mud is primarily composed of $\mathrm{Ca}, \mathrm{Si}$, Fe and $\mathrm{Al}$ oxides. Other minor elements such as $\mathrm{Mg}, \mathrm{K}, \mathrm{Ti}$ and $\mathrm{Na}$ are also precipitated as solid phases. Additional details on the characteristics of red mud are given elsewhere [27]. Before preparing the novel coagulant, red mud placed in porcelain were calcined at various temperatures $(300,500,700$, $900{ }^{\circ} \mathrm{C}$ ) for $2 \mathrm{~h}$ in a 48000 electric meffle furnace (Keda Scientific Co., Ltd).The power was stirred at $30 \mathrm{~min}$ intervals during the heat treatment.

Hydrochloric pickle liquor of bauxite was obtained from Tianjin Dagang Flocculant Corporation, Tianjin, China. It was industrial grade. The chemical analysis of hydrochloric pickle liquor of bauxite showed that it contains $13.6 \% \mathrm{Al}_{2} \mathrm{O}_{3}$. The hydrochloric pickle liquor of bauxite is highly acidic and the $\mathrm{pH}$ of hydrochloric pickle liquor of bauxite is 1.7.

For comparison reasons, commercially available $\mathrm{PACl}$ containing $17 \% \mathrm{Al}_{2} \mathrm{O}_{3}$ obtained from Tianjin Dagang Flocculant Corporation, Tianjin, China was also examined.

The analysis of phosphate was carried out using the ascorbic acid method with a HACH DR/4000U spectrophotometer, according to APHA standard methods [28]. A pH meter (Orion) was used to measure the $\mathrm{pH}$ of solutions in experiments. All chemicals used in the experiments were analytic grade and all experiments were conducted in duplicate and the average values were used for analysis.

\subsection{Preparation of coagulation reagents}

Firstly, an aliquot of $200 \mathrm{ml}$ of pickle liquor was added to a threenecked flask and placed in an electric heat constant temperature water bath at atmospheric pressures. Secondly, varied amounts of red mud were introduced into the three-necked flask according to the weight/volume ratio of red mud/hydrochloric pickle liquor of bauxite (W/V, 5:100 to 45:100). Reaction temperatures were varied from $25{ }^{\circ} \mathrm{C}$ to $95{ }^{\circ} \mathrm{C}$ and reaction time were varied from $1 \mathrm{~h}$ to $5 \mathrm{~h}$ for optimization purposes. The mixture was stirred to improve the chemistry reaction time. Finally, the mixture was cooled at room temperature and the coagulants were prepared well.

\subsection{Performance of the produced coagulant}

Coagulation tests were performed by using synthetic water, actual municipal sewage and eutrophic water. All coagulation tests were conducted using a six-jar tester (FlocculatorJTY-6, Beijing Daiyuan Co., Beijing, China). Phosphate was the key factor we considered in testing the performance of the novel coagulant, so we just considered the phosphate removal efficiency of the coagulant in the treatment of synthetic water to get the optimum preparation conditions. The synthetic water was prepared by diluting a concentration $1 \mathrm{~g} \mathrm{P} \mathrm{L}^{-1}$ in $\mathrm{PO}_{4}^{3-}$ to the experimental concentration by adding tap water of very low hardness. The $\mathrm{pH}$ value and phosphate of the synthetic water were 7.0 and $1.0 \mathrm{mg} / \mathrm{L}$. For treating the synthetic water, the coagulant dose was kept constant at $50 \mathrm{mg} /$ L. The actual municipal sewage was taken from secondary effluent of Beixiaohe sewage treatment plant (Beijing, China). The original $\mathrm{pH}$ and phosphate of the municipal sewage were 7.5 and $3.20 \mathrm{mg} / \mathrm{L}$. The actual eutrophic water was taken from a lake in Beijing Zoo, Beijing, China. The original $\mathrm{pH}$ and phosphate of the eutrophic water were 7.6 and $0.12 \mathrm{mg} / \mathrm{L}$. The jar-test experimental conditions were: initial rapid mixing at $300 \mathrm{rpm}$ for $2 \mathrm{~min}$, followed by slow mixing at $100 \mathrm{rpm}$ for $20 \mathrm{~min}$ and final sedimentation for $30 \mathrm{~min}$. At the end of these experiments about $50 \mathrm{ml}$ of sample was withdraw $5 \mathrm{~cm}$ below the liquid surface for phosphate measurement.

In order to estimate the leaching potential of heavy metals from the new coagulant, the treated wastewater was separated off using $0.45 \mu \mathrm{m}$ filter membrane and analysis for heavy metals by Inductively Coupled Plasma Mass Spectrometer (Plasma Quad 3). 


\section{Results and discussion}

\subsection{Preparation of the composite coagulant}

When red mud was added into the hydrochloric pickle liquor of bauxite, $\mathrm{Al}_{2} \mathrm{O}_{3}, \mathrm{CaO}, \mathrm{Fe}_{2} \mathrm{O}_{3}, \mathrm{Na}_{2} \mathrm{O}$ and $\mathrm{Na}_{2} \mathrm{SiO}_{3}$ in red mud reacted quickly with the residual hydrochloric acid in hydrochloric pickle liquor of bauxite, and the dissolution would occur, as shown in Eqs. (1)-(5).

$$
\begin{aligned}
& \mathrm{Al}_{2} \mathrm{O}_{3}+6 \mathrm{HCl}=2 \mathrm{AlCl}_{3}+3 \mathrm{H}_{2} \mathrm{O} \text { (dissolution) } \\
& \mathrm{Fe}_{2} \mathrm{O}_{3}+6 \mathrm{HCl}=2 \mathrm{FeCl}_{3}+3 \mathrm{H}_{2} \mathrm{O} \text { (dissolution) } \\
& \mathrm{CaO}+2 \mathrm{HCl}=\mathrm{CaCl}_{2}+\mathrm{H}_{2} \mathrm{O} \text { (dissolution) } \\
& \mathrm{Na}_{2} \mathrm{O}+\mathrm{HCl}=\mathrm{NaCl}+\mathrm{H}_{2} \mathrm{O} \text { (dissolution) } \\
& \mathrm{Na}_{2} \mathrm{SiO}_{3}+\mathrm{HCl}=\mathrm{NaCl}+\mathrm{H}_{2} \mathrm{SiO}_{3} \text { (dissolution) }
\end{aligned}
$$

With the increase of red mud, the residual hydrochloric acid was gradually neutralized and the basicity of the mixture gradually increased, and the hydrolyzation of $\mathrm{Al}$ (III) and the Fe (III) would occur.

$$
\begin{aligned}
& 2 \mathrm{Al} \mathrm{Cl}_{3}+\mathrm{nH}_{2} \mathrm{O}=\mathrm{Al}_{2}(\mathrm{OH}) \mathrm{mCl}_{6-\mathrm{n}}^{-}+\mathrm{nCl}^{-}+\mathrm{nH}^{+} \text {(hydrolysis) } \\
& 2 \mathrm{FeCl}_{3}+\mathrm{nH}_{2} \mathrm{O}=\mathrm{Fe}_{2}(\mathrm{OH}) \mathrm{mCl}_{6-\mathrm{n}}^{-}+\mathrm{nCl}^{-}+\mathrm{nH}^{+} \text {(hydrolysis) }
\end{aligned}
$$

With the polymerization of hydroxyl, the copolymerization of the hydrolysis complexes formed by the $\mathrm{Al}$ (III), the $\mathrm{Fe}$ (III) and $\mathrm{SiO}_{3}$ (II) would occur. It can be classified as polysilicate ferro-aluminum chloride.

As shown in Table 1, red mud was mainly made up of metal oxides, exhibiting alkaline character. It could neutralize the hydrochloric acid in the hydrochloric pickle liquor of bauxite and then adjust the basicity of the solution, the dose of red mud not only affected the $\mathrm{Al}_{2} \mathrm{O}_{3}, \mathrm{CaO}, \mathrm{Fe}_{2} \mathrm{O}_{3}, \mathrm{Na}_{2} \mathrm{O}$ and $\mathrm{SiO}_{2}$ content of the prepared coagulant, but also influenced the basicity of the prepared coagulant. Reaction time affected the $\mathrm{Al}_{2} \mathrm{O}_{3}, \mathrm{CaO}, \mathrm{Fe}_{2} \mathrm{O}_{3}, \mathrm{Na}_{2} \mathrm{O}$ and $\mathrm{SiO}_{2}$ rate of red mud and the reaction extent between red mud and the hydrochloric pickle liquor of bauxite. Reaction temperature affected the $\mathrm{Al}_{2} \mathrm{O}_{3}, \mathrm{CaO}, \mathrm{Fe}_{2} \mathrm{O}_{3}$, $\mathrm{Na}_{2} \mathrm{O}$ and $\mathrm{SiO}_{2}$ dissolution rate of red mud and the reaction speed. In addition, calcination temperature of red mud also affected the $\mathrm{Al}_{2} \mathrm{O}_{3}$, $\mathrm{CaO}, \mathrm{Fe}_{2} \mathrm{O}_{3}, \mathrm{Na}_{2} \mathrm{O}$ and $\mathrm{SiO}_{2}$ dissolution rate of red mud $[29,30]$. Therefore, $\mathrm{W} / \mathrm{V}$ ratio, calcination temperature of red mud, reaction temperature and reaction time were considered as the four main factors in the preparation of the new coagulant.

\subsubsection{The effect of $W / V$ ratio}

Red mud dosage and hydrochloric pickle liquor of bauxite has a consideration effect on the phosphate removal. So, red mud dosage and hydrochloric pickle liquor of bauxite should be considered together to study the effect of them on the phosphate removal. In this study, W/V was identified as the weight/volume ratio of red mud/ hydrochloric pickle liquor of bauxite, and the unit of W/V was gram/ milliliter. To study the effect of $\mathrm{W} / \mathrm{V}$, the volume of hydrochloric pickle liquor of bauxite was kept constant at $200 \mathrm{ml}$, the reaction temperature was kept constant at $80{ }^{\circ} \mathrm{C}$, while varying the dosage of red mud uncalcined. The effect of $\mathrm{W} / \mathrm{V}$ on the phosphate removal efficiency is shown in Fig. 1. As seen from Fig. 1, the removal of phosphate increases as W/V increases up to 35:100. Generally, the higher $\mathrm{w} / \mathrm{v}$ of the coagulant, the more metal ions dissolved from red mud and the higher the polymerization extent formed by the hydrolyzing $\mathrm{Al}^{3+}$ and $\mathrm{Fe}^{3+}$ due to the increase of basicity of the coagulant $[31,32]$. The more metal ions extracted from red mud and the higher the polymerization extent formed by the hydrolyzing $\mathrm{Al}^{3+}$

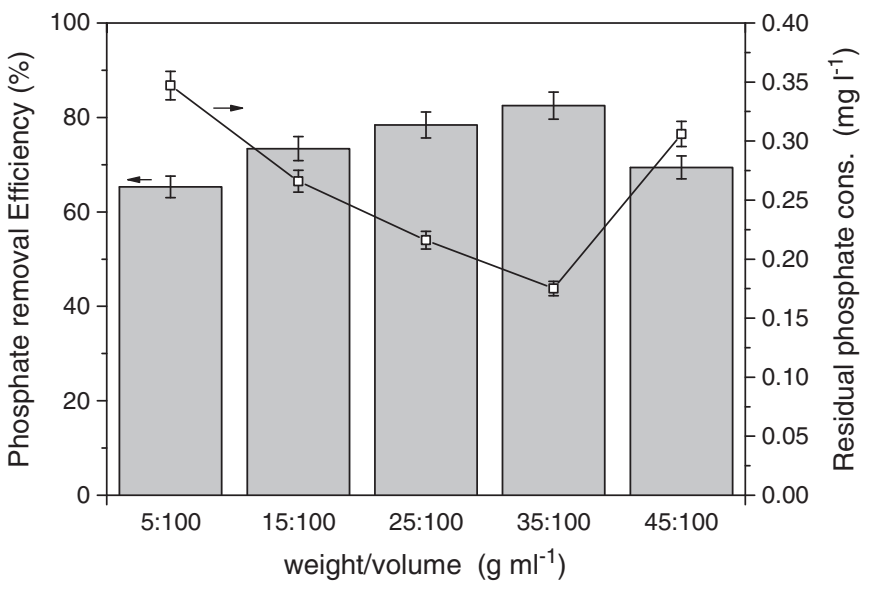

Fig. 1. Effect of weight/volume ratio on phosphate removal.

and $\mathrm{Fe}^{3+}$, the stronger the charge neutralizing and adsorptionbridging capacity of the coagulant. The stronger the charge neutralizing and adsorption-bridging capacity of the coagulant, the better the coagulation performance of the coagulant. However, if $\mathrm{W} / \mathrm{V}$ of the coagulant was too high ( $>35: 100$ ), the basicity of the coagulant would increase further and the metals such as $\mathrm{Al}^{3+}$ and $\mathrm{Fe}^{3+}$ in the coagulant might easily hydrolyze and sedimentate, leading to the decrease of the dissolved metals content of the coagulant and decreasing the coagulation performance and stability of the coagulant. For above reasons, 35:100 was considered as the optimum $\mathrm{W} / \mathrm{V}$.

\subsubsection{The effect of calcination temperature of red mud}

Red mud was calcined at $300{ }^{\circ} \mathrm{C}, 500{ }^{\circ} \mathrm{C}, 700{ }^{\circ} \mathrm{C}$ and $900{ }^{\circ} \mathrm{C}$ for $2 \mathrm{~h}$ and then the calcined red mud was reacted with hydrochloric pickle liquor of bauxite with $\mathrm{W} / \mathrm{V}$ ratio 35:100 to prepare coagulants. The effect of calcination temperature of red mud on the removal of the phosphate from aqueous solution is shown in Fig. 2. As seen from Fig. 2, the removal of phosphate rapidly increases as calcination temperature increases up to $700{ }^{\circ} \mathrm{C}$ and thereafter, it increases slowly. Optimum calcination temperature of red mud for the preparation of the coagulant is $700{ }^{\circ} \mathrm{C}$. The removal efficiency of composite coagulant prepared using red mud calcined under $700{ }^{\circ} \mathrm{C}$ for $1 \mathrm{mg} \mathrm{l}^{-1}$ phosphate solution reached $92.0 \%$. This could be explained by the effect of calcination temperature on the extraction of metals from red mud. At low calcination temperatures $\left(<700^{\circ} \mathrm{C}\right)$, the evaporation of physically adsorbed water and the loss of chemically adsorbed water from goethite and gibbsite occurred, also the decomposition of calcite $\left(\mathrm{CaCO}_{3}\right)$ into $\mathrm{CaO}[27,29,30]$. All these made metals more easily

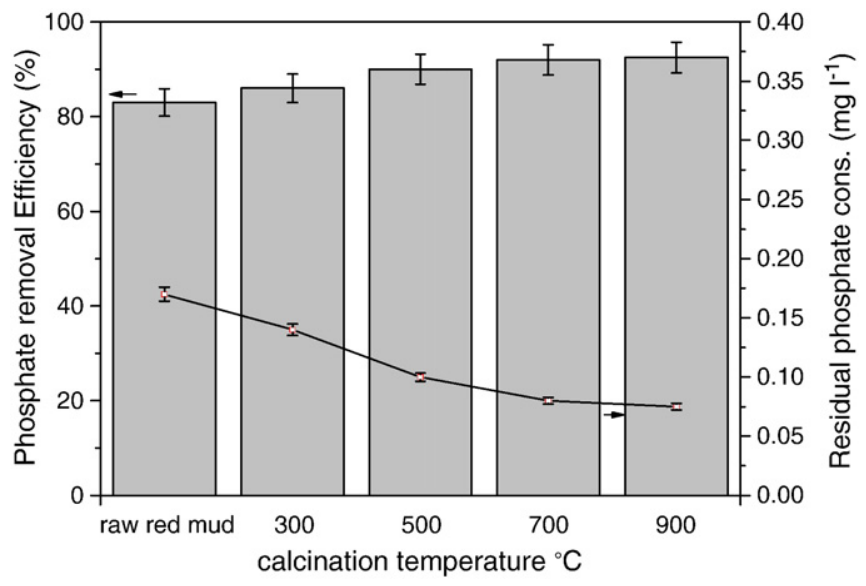

Fig. 2. Effect of calcination temperature on phosphate removal. 
extracted from red mud $[10,33]$. At high calcination temperatures $\left(>700{ }^{\circ} \mathrm{C}\right)$, more metals were extracted from red mud, but the quantity of the dissolved metals extracted from red mud increased slowly due to the sintering shrinkage of red mud. For above reasons, $700{ }^{\circ} \mathrm{C}$ was considered as the optimum calcination temperature of red mud.

\subsubsection{The effect of reaction temperature}

In order to study the effect of reaction temperature, the red mud was calcined at $700{ }^{\circ} \mathrm{C}$ for $2 \mathrm{~h}$, the W/V was kept constant at $35: 100$ and the reaction time was kept constant $4 \mathrm{~h}$, while varying the reaction temperature. The coagulation performance of different new coagulants prepared at different reaction temperatures is shown in Fig. 3. As seen from Fig. 3, phosphate removal efficiency increased with the increase of reaction temperature (from $25^{\circ} \mathrm{C}$ to $80{ }^{\circ} \mathrm{C}$ ), followed by no increase after the reaction temperature was higher than $80^{\circ} \mathrm{C}$. The phosphate removal efficiency of the coagulant prepared at $80^{\circ} \mathrm{C}$ was the highest. This can be explained by reaction rate theory, which holds that the rate of a chemical reaction increases with temperature [31,32]. Reaction temperature affected the effective elements dissolution rate of red mud and the reaction rate. Generally, higher reaction temperature could make the reaction extent between red mud and hydrochloric pickle liquor of bauxite higher. This made more effective elements dissolved from red mud and also increased the basicity of the coagulant. But if the reaction temperature was too high $\left(>80^{\circ} \mathrm{C}\right)$, reaction temperature would have no significant influence on the quantity of the effective elements dissolved from red mud and the stability of the coagulant would decrease significantly. Furthermore, higher reaction temperature would need more energy for preparing the coagulant, which might prevent the industrial preparation and application of the coagulant. Therefore, optimum reaction temperature of red mud and hydrochloric pickle liquor of bauxite for the preparation of the coagulant is $80^{\circ} \mathrm{C}$.

\subsubsection{The effect of reaction time}

In order to study the effect of reaction time, the red mud was calcined at $700{ }^{\circ} \mathrm{C}$ for $2 \mathrm{~h}$, the $\mathrm{W} / \mathrm{V}$ was kept constant at $35: 100$ and the reaction temperature was kept $80^{\circ} \mathrm{C}$, while varying the reaction time. The experimental results were shown in Fig. 4. Fig. 4 showed that phosphate removal efficiency increased rapidly with the increase of reaction time (from $1 \mathrm{~h}$ to $4 \mathrm{~h}$ ), followed by slowly increase after the reaction time was higher than $4 \mathrm{~h}$. Reaction time affected the effective elements dissolution rate of red mud and the reaction extent between red mud and hydrochloric pickle liquor of bauxite [31,32]. The longer the reaction time, the higher the utilization rate of red mud and the higher the reaction extent between red mud and hydrochloric pickle liquor of bauxite. But if the reaction time was too long, a little

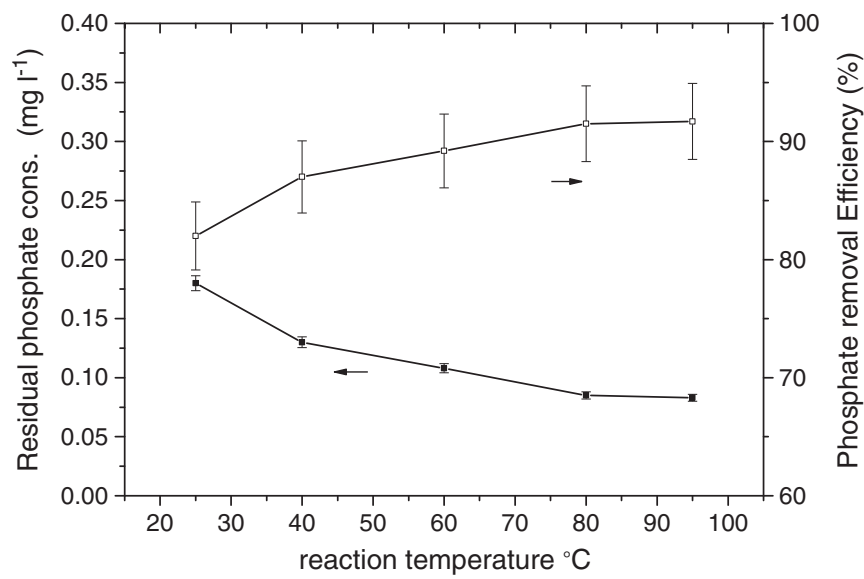

Fig. 3. Effect of reaction temperature on phosphate removal.

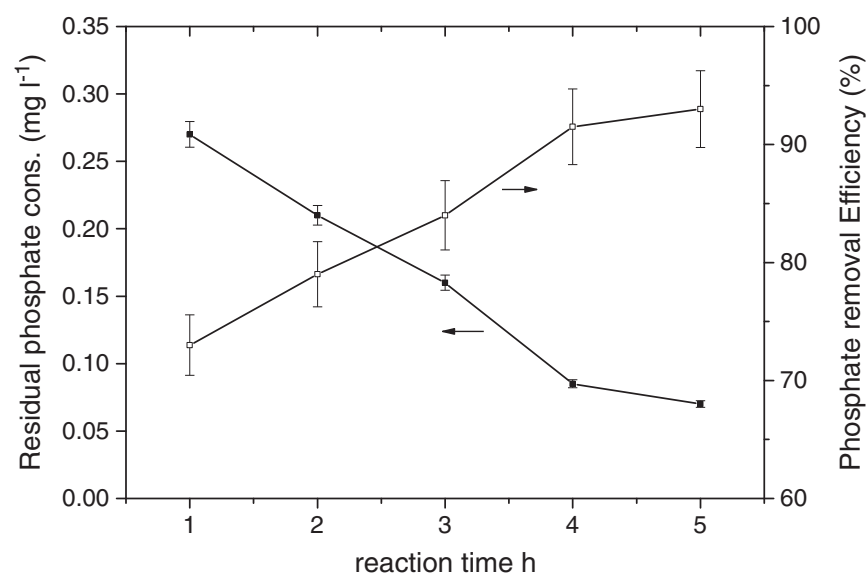

Fig. 4. Effect of reaction time on phosphate removal.

increase in the effective compositions of the coagulant and more energy would be needed, which was not economic. Therefore, the optimum reaction time of red mud and hydrochloric pickle liquor of bauxite for the preparation of the coagulant is $4 \mathrm{~h}$. The characteristics of the new coagulant synthesized under the above optimum conditions (W/V35:100, calcination temperature of red mud $700{ }^{\circ} \mathrm{C}$, reaction temperature $80^{\circ} \mathrm{C}$, reaction time $4 \mathrm{~h}$ ) was shown in Table 2 . The coagulant produced at optimum conditions was used for the further experiments.

\subsection{Performance of the prepared coagulant}

\subsubsection{The effect of $p H$}

The $\mathrm{pH}$ of the aqueous solutions is an important variable. The impact of $\mathrm{pH}$ variation on the coagulation performance was investigated and the results were shown in Fig. 5. As can be seen from Fig. 5, pH had important influence on phosphate removal efficiency of the composite coagulant. The best performance for the coagulant occurs at $\mathrm{pH}$ value 6 , indicating the importance of $\mathrm{Al}(\mathrm{OH})_{3}$ formation and its participation for the removal of phosphates [34,35]. Because $\mathrm{Al}^{3+}$ was the major element of the coagulant and the main mechanism of coagulation with the novel coagulant is the formation of insoluble $\mathrm{Al}(\mathrm{OH})_{3}$, which was favored at $\mathrm{pH}$ 6. At $\mathrm{pH}$ higher than 6 , the phosphate removal tended to decrease slightly, due to the competition with hydroxide ions on adsorbent surface. In other words a high bias in the measured concentration could occur at $\mathrm{pH}$ values above 9 due to presence of high concentration of $\mathrm{OH}^{-}$. At acidic $\mathrm{pH}(<6)$, It was evident that the performance was markedly dropped down to an unsatisfactory level. At this relatively low $\mathrm{pH}$, the neutralization of negatively charged phosphate with the positively charged metal species such as aluminum species was hindered by the presence of $\mathrm{H}_{3} \mathrm{O}^{+}$cations, as they compete for the electrostatic interaction with the negative functional groups of colloids.

The solution $\mathrm{pH}$ relative to the point of zero charge ( $\mathrm{pHpzc}$ ) for the colloidal particles was also considered and the results were shown in Fig. 6. At pH values above the pHpzc of the adsorber, the surface of adsorber particles is negatively charged and as the $\mathrm{pH}$ rises above the pHpzc, anion adsorption decreases. The pHpzc for the colloidal

Table 2

Characteristics of the new coagulant ${ }^{\mathrm{a}}$

\begin{tabular}{llllllll}
\hline $\begin{array}{l}\mathrm{pH} \\
(1 \% \mathrm{~s} \ln )\end{array}$ & $\begin{array}{l}\text { Density } \\
\left(\mathrm{g} / \mathrm{cm}^{3}\right)\end{array}$ & $\begin{array}{l}\text { Solid content } \\
(\%)\end{array}$ & $\begin{array}{l}\text { Basicity } \\
(\%)\end{array}$ & $\mathrm{Al}_{2} \mathrm{O}_{3}$ & $\mathrm{SiO}_{2}$ & $\mathrm{CaO}$ & $\mathrm{Fe}_{2} \mathrm{O}_{3}$ \\
\hline 2.1 & 1.24 & 41.0 & 32 & 12.44 & 2.95 & 6.31 & 3.51 \\
\hline
\end{tabular}

a Data from coagulant produced at optimum conditions (W/V35:100, calcination temperature of red mud $700{ }^{\circ} \mathrm{C}$, reaction temperature $80{ }^{\circ} \mathrm{C}$, reaction time $4 \mathrm{~h}$ ). 


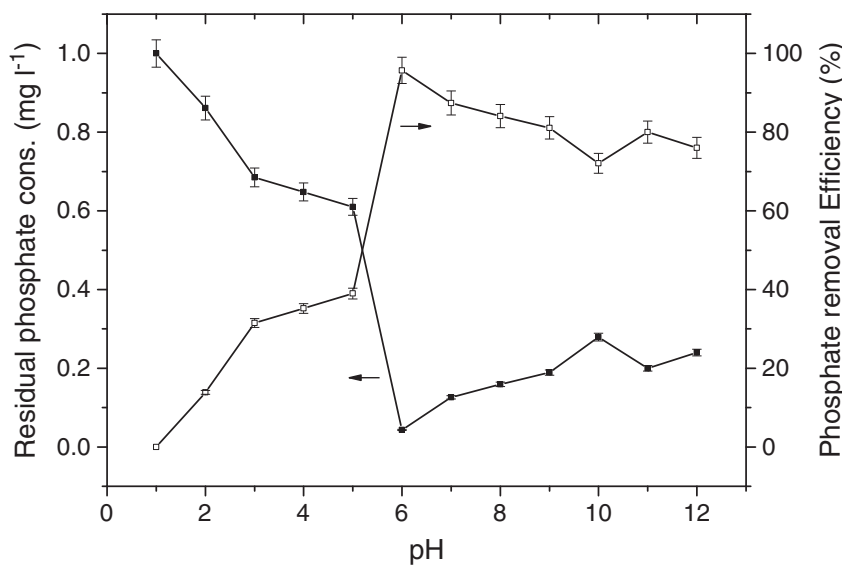

Fig. 5. Effect of pH on phosphate removal.

particles was 6.2, which was in agreement with the optimum $\mathrm{pH}$ for phosphate removal. This showed that charge neutralization was the main mechanism of the coagulant for phosphate removal.

For the prepared coagulant, coagulation is the operation mechanism for phosphate removal. Coagulation involves hydrolysis, adsorption, and precipitation processes.

When the prepared coagulant was added to the wastewater, $\mathrm{Al} / \mathrm{Fe}$ (III) ions in the coagulant hydrolyze to form soluble monomeric and polymeric species and solid precipitates. For $\mathrm{Al} / \mathrm{Fe}(\mathrm{III})$ ions, it mainly depended on the destabilization-adsorption mechanism for phosphate removal $[36,37]$. Dosing the coagulant consisting of Al or Fe salts into wastewater leads to $\mathrm{Al}^{3+}$ or $\mathrm{Fe}^{3+}$ ions hydrolyzing rapidly, forming a range of hydrolysis species, and ultimately, metal hydroxide. Simple $\mathrm{Al}^{3+}$ or $\mathrm{Fe}^{3+}$ ions are unlikely to exist in such water bodies and therefore, the $\mathrm{AlPO}_{4}$ and $\mathrm{FePO}_{4}$ might not form or only form to a limited extent due to competition reactions between the $\mathrm{Al}^{3+}$ or $\mathrm{Fe}^{3+}$ ion hydrolysis and $\mathrm{PO} 4$ precipitation. In general, two major mechanisms have been considered to be linked to the coagulation of $\mathrm{PO}_{4}$ with the prepared coagulant containing $\mathrm{Al} / \mathrm{Fe}(\mathrm{III})$ salts: (1) Formation of $\mathrm{Al} / \mathrm{Fe}$-hydroxo-phosphate complexes. These complexes either adsorb on to positively charged $\mathrm{Al} / \mathrm{Fe}$ (III) hydrolysis species or act as centers of precipitation for $\mathrm{Al} / \mathrm{Fe}(\mathrm{III})$ hydrolysis products. (2) Adsorption of $\mathrm{PO}_{4}$ ions on to the $\mathrm{Al} / \mathrm{Fe}(\mathrm{III})$ hydrolysis species. In the case of using the prepared coagulant, polymeric species are the predominant hydrolysis species in water treatment practice, and $\mathrm{PO}_{4}$ ions may complex with the positive sites of such species.

For Ca ions in the prepared coagulant, chemical precipitation was the mechanism. The use of Ca ions led to the direct formation of insoluble precipitation of phosphate in water treatment. The process

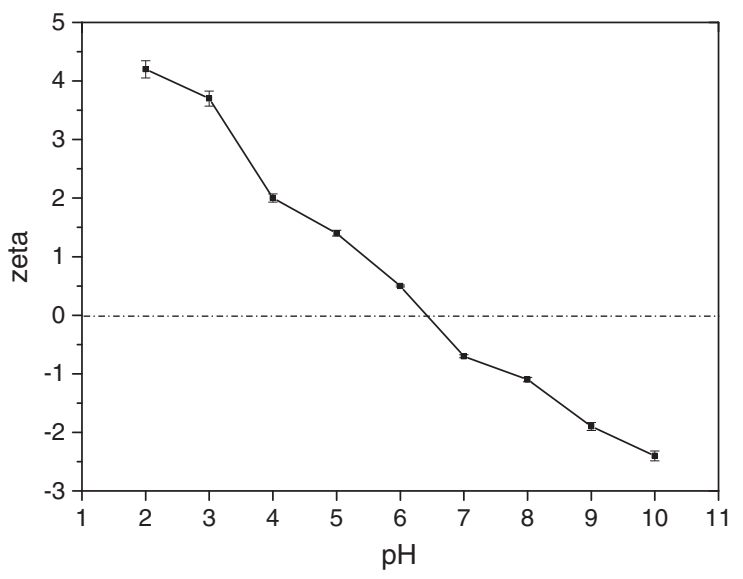

Fig. 6. Effect of $\mathrm{pH}$ on zeta potential. is related to the compound solubility and the removal of phosphate from water by precipitation depends on the solubility of the various complexes formed in water.

For silica in the prepared coagulant, the introduction of silica chains into the structure of the coagulant has proved increases in the molecular weight (MW) of the coagulants [38,39], thus leading to enhanced aggregating power and bigger and denser flocs' formation.

\subsubsection{The effect of ionic strength}

Solution chemistry has considerable influence on coagulation by hydrolyzing metal ions. To study the effect of addition of electrolyte on phosphate removal of the new coagulant, phosphate removal of the synthetic water as a function of $\mathrm{NaCl}$ dosage was investigated and the results were shown in Fig. 7. As seen from Fig. 7, the addition of $\mathrm{NaCl}$ had significant effect on phosphate removal of the new coagulant. The phosphate removal efficiency increased rapidly at low ionic strength, and then increased slowly at relative high ionic strength. The ionic strength influence can be explained by a classical idea of colloid stability [34]. Generally, the higher the ionic strength, the more the reduction in the zeta potential and the more decreased is thickness of the diffuse part of the electrical double layer. The more the reduction in the zeta potential and the more decreased is thickness of the diffuse part of the electrical double layer, the higher the phosphate removal efficiency of the coagulant.

\subsubsection{The effect of temperature}

The effect of temperature on the removal of the phosphate from aqueous solution at $\mathrm{pH}=7.0$ is shown in Fig. 8. It is apparent that the phosphate removal efficiency decreased slowly with decreasing temperature of aqueous solution. The effects of temperature on phosphate removal could be explained by the physical or chemical influence. Physically, water temperature may have influence on particle transport processes or particle collision rates, mainly through the effect on viscosity, and thus on the mixing energy dissipated in water. With decreasing temperature, the viscosity increased and the poor rapid-mixing conditions caused by low water temperature might lead to inhomogeneous distribution of coagulant species in the water, which resulted in a poor phosphate removal [33]. Chemically, variation of water temperature may be related to the effect on hydrolysis reactions, precipitation and solubility of the metal hydroxide. With decreasing temperature, the rate of hydrolysis of metal salts was decelerated and the formation time of soluble polymeric iron species increased rapidly. The lower phosphate removal at low temperature may be also attributed to the floc characteristics. At low temperature, flocs were formed slowly and were smaller than those formed at normal temperature.

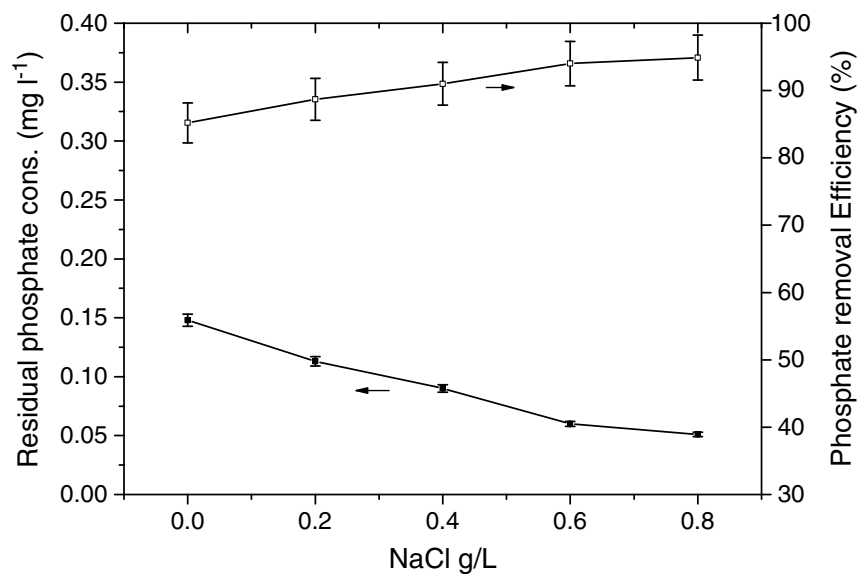

Fig. 7. Effect of ionic strength on phosphate removal. 


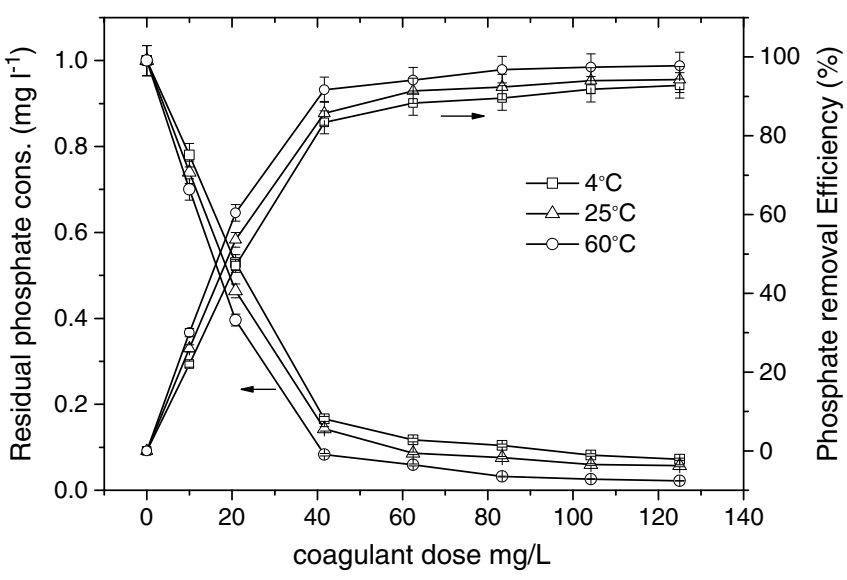

Fig. 8. Effect of temperature on phosphate removal.

3.3. Application of the coagulant in biologically pre-treated municipal wastewater and eutrophic water

\subsubsection{Application of the coagulant in biologically pre-treated municipal sewage}

In order to investigate the coagulation performance of the new coagulant, it was applied in the treatment of biologically pre-treated municipal sewage and compared with conventional PACl coagulant. The result of the comparison of the performance the new coagulant and conventional PACl coagulant was presented in Fig. 9. As seen from Fig. 9, the phosphate removal efficiency was evidently higher than that of $\mathrm{PACl}$ in the treatment of biologically pre-treated municipal wastewater. In the range of dosage researched, compared with $\mathrm{PACl}$, the new coagulant could promote phosphate removal efficiency from $4.9 \%$ to $10.4 \%$. With the phosphate removal efficiency of $84.6 \%$ (in order to satisfy the discharge standards of phosphate $\leq 0.5 \mathrm{mg} / \mathrm{L}$ ), the dosages of the new coagulant and $\mathrm{PACl}$ were $70 \mathrm{mg} / \mathrm{L}$ and $80 \mathrm{mg} / \mathrm{L}$, respectively. Therefore, at same phosphate removal level, the consumption of the coagulant is much less than $\mathrm{PACl}$, and leaves less iron or aluminum residue in the treated water. The treatment results proved that the new coagulant could be effectively used for the tertiary treatment of biologically pre-treated municipal wastewater.

\subsubsection{Application of the coagulant in eutrophic water}

In order to investigate the coagulation performance of the new coagulant, it was also applied in the treatment of eutrophic water and compared with conventional PACl coagulant. The performance of the complex coagulant at different dosages for phosphate removal was

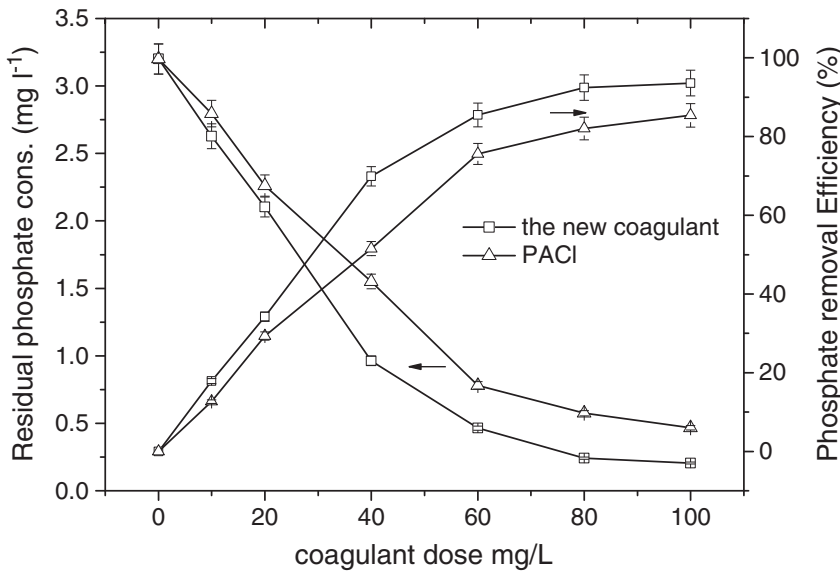

Fig. 9. Effect of coagulant dose on phosphate removal for municipal sewage.

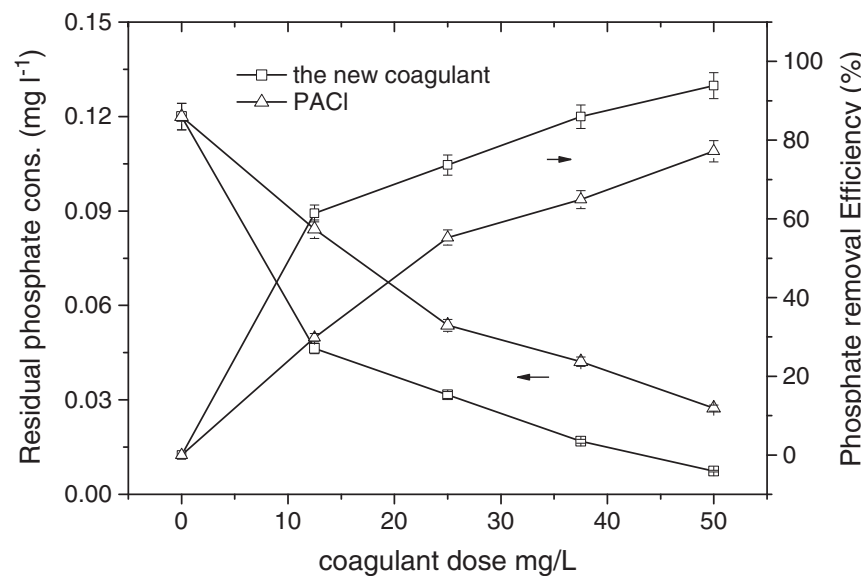

Fig. 10. Effect of coagulant dose on phosphate removal for eutrophic water.

presented in Fig. 10. This figure showed that an optimal dosage of $37.5 \mathrm{mg} / \mathrm{L}$ complex coagulant reduced the phosphate in values lower than $0.02 \mathrm{mg} / \mathrm{L}$, which is the limit value for eutrophic water. But for $\mathrm{PACl}$, it is difficult to reduce the phosphate in values lower than $0.02 \mathrm{mg} / \mathrm{L}$ even when the dosage of $\mathrm{PACl}$ reached $50 \mathrm{mg} / \mathrm{L}$. Therefore, the new coagulant had better performance for phosphate removal compared with $\mathrm{PACl}$ in the treatment of eutrophic water.

\subsection{The leaching potential of heavy metals from the new coagulant}

The estimation of the leaching potential of the coagulant is important in assessing the possible impacts associated with the coagulant. The data reported in Table 3 was the average of three duplicate runs with samples. As seen from Table 3, all measured parameters were significantly lower compared to maximum allowed values prescribed by Chinese EPA standards (GB5749-2006). This confirmed that the coagulant is not hazardous, i.e., it does not pose a substantial threat to human health and living organisms.

\section{Conclusion}

The new composite coagulant prepared by red mud and hydrochloric pickle liquor of bauxite had a good coagulation performance. It could reduce the phosphate in values lower than $0.02 \mathrm{mg} / \mathrm{L}$. The phosphate removal efficiency of the new coagulant was better than that of conventional PACl coagulant in the treatment of biologically pre-treated municipal wastewater and eutrophic water. Compared with commercial polyaluminum chloride coagulant ( $\mathrm{PACl})$, it could promote phosphate removal efficiency from $4.9 \%$ to $10.4 \%$. The leaching test of heavy metals from the new coagulant confirmed that the coagulant is not hazardous.

\section{Acknowledgements}

The authors are grateful for financial support provided by National Key Technology R\&D Program (2009BADC2B04), National S\&T Major Project (under Grant No. 2009ZX07104-005), and the National High Technology R\&D Program (863) from Ministry of Science and

Table 3

The concentration of heavy metals in solutions and comparison with the Chinese. EPA standards.

\begin{tabular}{lllllllll}
\hline & $\mathrm{Cr}$ & $\mathrm{Ni}$ & $\mathrm{Cu}$ & $\mathrm{Zn}$ & $\mathrm{As}$ & $\mathrm{Cd}$ & $\mathrm{Pb}$ & $\mathrm{Hg}$ \\
\hline Heavy metal $(\mathrm{mg} / \mathrm{L})$ & - & - & - & 0.23 & - & - & & \\
Regulatory limit $(\mathrm{mg} / \mathrm{L})$ & 0.05 & 0.02 & 1.0 & 1.0 & 0.01 & 0.005 & 0.01 & 0.001 \\
\hline
\end{tabular}

Note: “" means lower than the detection limit. 
Technology of China (under Grant Nos. 2009AA062906 and 2008AA06A409-3).

\section{References}

[1] J.W. Choi, S.Y. Lee, K.Y. Park, K.B. Lee, D.J. Kim, S.H. Lee, Investigation of phosphorous removal from wastewater through ion exchange of mesostructure, Desalination 266 (2011) 281-285.

[2] Y.H. Song, P. Yuan, B. Zheng, J. Peng, F. Yuan, Y. Gao, Nutrients removal and recovery by crystallization of magnesium ammonium phosphate from synthetic swine wastewater, Chemosphere 69 (2007) 319-324.

[3] Y.H. Song, D. Donnert, U. Berg, P.G. Weidler, R. Nueesch, Seed selections for crystallization of calcium phosphate for phosphorus recovery, J. Environ. Sci. 19 (2007) 591-595.

[4] Y.H. Song, P.G. Weidler, U. Berg, R. Nueesch, D. Donnert, Calcite-seeded crystallization of calcium phosphate for phosphorus recovery, Chemosphere 63 (2006) 236-243.

[5] J. Gao, Z. Xiong, J. Zhang, W. Zhang, F.O. Mba, Phosphorus removal from water of eutrophic Lake Donghu by five submerged macrophytes, Desalination 242 (2009) 193-204.

[6] K.G. Song, J. Cho, K.W. Cho, S.D. Kim, K.H. Ahn, Characteristics of simultaneous nitrogen and phosphorus removal in a pilot-scale sequencing anoxic/anaerobic membrane bioreactor at various conditions, Desalination 250 (2010) 801-804.

[7] F. Ying Test, Characterization and phosphorus removal of poly-silicic-ferric coagulant, Desalination 247 (2009) 442-455.

[8] E. Vaiopoulou, P. Melidis, A. Aivasidis, Growth of filamentous bacteria in an enhanced biological phosphorus removal system, Desalination 213 (2007) 288-296.

[9] H. Sarparastzadeh, M. Saeedi, F. Naeimpoor, B. Aminzadeh, Pretreatment of municipal wastewater by enhanced chemical coagulation, Int. J. Environ. Res. 1 (2007) 104-113.

[10] Y.Z. Li, C.J.L, Z.K.L, Phosphate removal from aqueous solutions using raw and activated red mud and fly ash, J. Hazard. Mater. B 137 (2006) 374-383.

[11] H.S. Altundogan, F. Tumen, Removal of phosphates from aqueous solutions by using bauxite. I: Effect of $\mathrm{pH}$ on the adsorption of various phosphates, J. Chem. Technol. Biotechnol. 77 (2002) 77-85.

[12] H.S. Altundogan, F. Tumen, Removal of phosphates from aqueous solutions by using bauxite. II: The activation study, J. Chem. Technol. Biotechnol. 78 (2003) 824-833.

[13] D. Mulkerrins, A.D.W. Dobson, E. Colleran, Parameters affecting biological phosphate removal from wastewaters, Environ. Int. 2 (30) (2004) 249-259.

[14] Ying Zhao, Jun Wang, Zhaokun Luan, Xianjia Peng, Zhen Liang, Li. Shi, Removal of phosphate from aqueous solution by red mud using a factorial design, J. Hazard. Mater. 165 (1-3) (2009) 1193-1199.

[15] D.A. Georgantas, H.P. Grigoropoulou, Phosphorus removal from synthetic and municipal wastewater using spent alum sludge, Water Sci. Technol. 52 (10-11) (2005) 525-535.

[16] E. Poulin, J.F. Blais, G. Mercier, Transformation of red mud from aluminium industry into a coagulant for wastewater treatment, Hydrometallurgy 92 (1-2) (2008) 16-25.

[17] Q. Wang, Z. Luan, N. Wei, J. Li, C. Liu, The color removal of dye wastewater by magnesium chloride/red mud (MRM) from aqueous solution, J. Hazard. Mater 170 (2009) 690-698.
[18] Q. Wang, Z. Luan, X. Peng, L. Shi, Recovery of alkali in red mud using $\mathrm{CO}_{2}$, Fresenius Environ. Bull. 18 (2009) 2345-2351.

[19] H. Nadaroglu, E. Kalkan, N. Demir, Removal of copper from aqueous solution using red mud, Desalination 251 (2010) 90-95.

[20] U. Danıș, Chromate removal from water using red mud and crossflow microfiltration, Desalination 181 (2005) 135-143.

[21] A. Tor, Y. Cengeloglu, M. Ersoz, Increasing the phenol adsorption capacity of neutralized red mud by application of acid activation procedure, Desalination 242 (2009) 19-28.

[22] R.C. Sahu, R. Patel, B.C. Ray, Adsorption of Zn(II) on activated red mud: neutralized by $\mathrm{CO}_{2}$, Desalination 266 (2011) 93-97.

[23] N. Chen, Z. Zhang, C. Feng, M. Li, R. Chen, N. Sugiura, Investigations on the batch and fixed-bed column performance of fluoride adsorption by Kanuma mud, Desalination 268 (2011) 76-82.

[24] S.B. Wang, Y. Boyjoo, A. Choueib, Z.H. Zhu, Removal of dyes from aqueous solution using fly ash and red mud, Water Res. 39 (1) (2005) 129-138.

[25] Édith Poulin, Jean-François Blais, Guy Mercier, Transformation of red mud from aluminium industry into a coagulant for wastewater treatment, Hydrometallurgy $92(1-2)(2004) 16-25$.

[26] R.K. Paramguru, P.C. Rath, V.N. Misra, Trends in red mud utilization - a review Miner. Process. Extr. Metall. Rev. 26 (1) (2005) 1-29.

[27] Ying Zhao, Jun Wang, Changjun Liu, Zhaokun Luan, Ning Wei, Zhen Liang, Characterization and risk assessment of red mud derived from the sintering alumina process, Fresenius Environ. Bull. 18 (6) (2009) 989-993.

[28] E. Arnold, Standard Methods for the Examination of Water and Wastewater, 16th ed, American Public Health Association, Washington, DC, New York, 1985, pp. $445-446$

[29] A. Atasoy, An investigation on characterization and thermal analysis of the Aughinish red mud, J. Therm. Anal. Calorim. 81 (2) (2005) 357-361.

[30] A. Atasoy, The comparison of the Bayer process wastes on the base of chemical and physical properties, J. Therm. Anal. Calorim. 90 (1) (2007) 153-158.

[31] D. Uzun and M. Gulfen, Dissolution kinetics of iron and aluminium from red mud in sulphuric acid solution, Indian. J. Chem. Technol. 14(2007), 263-268.

[32] L. Wei, H. Qiu, J. Zhang, Y. Yu, K. Yang, Z. Liu and G. Ding, Characteristic of a novel composite inorganic polymer coagulant-PFAC prepared by hydrochloric pickle liquor, J. Hazard. Mater. 162 (2009), 174-179.

[33] Y.N. Zhang, Z.H. Pan, Characterization of red mud thermally treated at different temperatures, J. Jinan Univ. (Sci. Technol.) 19 (4) (2005) 35-38.

[34] J.Q. Jiang, N.J.D. Graham, Pre-polymerised inorganic coagulants and phosphorus removal by coagulation - a review, Water SA 24 (3) (1998) 237-244.

[35] S. Smith, I. Takacs, S. Murthy, Phosphate complexation model and its implications for chemical phosphorus removal, Water Environ. Res. 80 (5) (2008) 428-438.

[36] J.T. Boisvert, T.C. Berrak, Phosphate adsorption in flocculation processes of aluminium sulphate and poly-aluminium-silicate-sulphate, Water Res. 8 (31) (1997) 1939-1946.

[37] D.A. Georgantas, H.P. Grigoropoulou, Orthophosphate and metaphosphate ion removal from aqueous solution using alum and aluminum hydroxide, J. Colloid Interface Sci. 315 (2007) 70-79.

[38] B.Y. Gao, Q.-Y. Yue, Y. Wang, Coagulation performance of polyaluminum silicate chloride (PASiC) for water and wastewater treatment, Sep. Purif. Technol. 56 (2007) 225-230.

[39] B.Y. Gao, Q.-Y. Yue, B.J. Wang, Y.B. Chu, Poly-aluminum-silicate-chloride (PASic) a new type of composite inorganic polymer coagulant, Colloids Surf. A 229 (2003) 121-127. 